\title{
Ameliorative Potential of Clerodendrum volubile Ethanol Leaf Extract on Doxorubicin-Induced Hepatorenal Toxicities in Rats
}

\author{
Adejuwon A. Adeneye ${ }^{1 *}$, Olufunke E. Olorundare ${ }^{2}$, Akinyele O. Akinsola ${ }^{2}$, Daniel A. Sanni ${ }^{3}$, \\ Ikechukwu I. Okoye ${ }^{4}$, James M. Ntambi ${ }^{5}$, Hasan Mukhtar ${ }^{6}$
}

\begin{abstract}
${ }^{I}$ Department of Pharmacology, Therapeutics and Toxicology, Faculty of Basic Clinical Sciences, Lagos State University College of Medicine, 1-5 Oba Akinjobi Way, G.R.A., Ikeja, Lagos State, Nigeria. ${ }^{2}$ Department of Pharmacology and Therapeutics, Faculty of Clinical Sciences, College of Health Sciences, University of Ilorin, Ilorin, Kwara State, Nigeria. ${ }^{3,4}$ Department of Pathology and Forensic Medicine, Faculty of Basic Clinical Sciences, Lagos State University College of Medicine, 1-5 Oba Akinjobi Way, G.R.A., Ikeja, Lagos State, Nigeria. ${ }^{5}$ Department of Biochemistry, University of Wisconsin, Madison, 433 Babcock Drive, Madison WI, 53706, USA. ${ }^{6}$ Department of Dermatology, University of Wisconsin, Madison, Medical Science Center, 1300 University Avenue, Madison, WI 53706, U.S.A
\end{abstract}

"Corresponding Author Email: adejuwon.adeneye@lasucom.edu.ng

Phone: +2348035835589

\section{ARTICLE HISTORY \\ Received: $9^{\text {th }}$ April, 2021 \\ Accepted: $9^{\text {th }}$ August, 2021}

\section{KEYWORDS}

Clerodendrum volubile leaf extract; Doxorubicin hepato- renal toxicities; Free radical scavenging/antioxidant

\section{Pharmacology and Toxicology of Natural Medicines ISSN: 2756-6838}

Published by Phytomedicine Research Group, Department of Pharmacology \& Toxicology, Faculty of Pharmacy, University of Benin, Benin City 300001, Nigeria

\section{ABSTRACT}

Background and Purpose: Hepatorenal toxicity is a side effect of the anthracycline cytotoxic antibiotics, doxorubicin that is used in cancer treatment. The study investigated the ameliorative potential of Clerodendrum volubile ethanol leaf extract $(C V E)$ on doxorubicin (DOX)-induced hepatorenal toxicities.

Methods: Male Wistar rats were pretreated with Clerodendrum volubile ethanol leaf extract $(50-400 \mathrm{mg} / \mathrm{kg} / \mathrm{day}, \mathrm{p} . \mathrm{o})$ followed by intraperitoneal injection of $2.5 \mathrm{mg} / \mathrm{kg}$ of DOX on alternate days for 14 days. Hepatorenal toxicity was assessed using renal function parameters (serum electrolytes, blood urea and creatinine), hepatic function endpoints [aspartate aminotransferase (AST), alanine aminotransferase (ALT) and alkaline phosphatase (ALP), total protein (TP), albumin (ALB) and total bilirubin (TB)]. In addition, the antioxidant activity in the kidney and liver tissues were assayed and histological studies of these tissues were also conducted.

Results: Oral pretreatment with $50 \mathrm{mg} / \mathrm{kg} / \mathrm{day}, 100 \mathrm{mg} / \mathrm{kg} / \mathrm{day}, 200 \mathrm{mg} / \mathrm{kg} / \mathrm{day}$ and 400 $\mathrm{mg} / \mathrm{kg} /$ day of $C V E$ remarkably ameliorated DOX-induced liver and kidney injury by lowering the serum ALT, AST, ALP, Cr and BUN levels. CVE pretreatment remarkably ameliorated DOX-induced increases in the CAT, SOD and GPx activities and MDA levels compared to the DOX-treated rats. The biochemical changes were corroborated by improvements in the DOX-induced histological lesions seen in the hepatic and renal tissues examined.

Conclusions: Overall, these findings suggest that Clerodendrum volubile ethanol leaf extract elicits protective effect against DOX-induced hepatorenal toxicities mediated primarily via oxidative stress suppression and improvement in the free radicals scavenging activities of CVE.

LICENSE: This article by Pharmacology and Toxicology of Natural Medicines is licensed and published under the Creative Commons Attribution License 4.0 which permits unrestricted use, distribution, and reproduction in any medium, provided this article is duly cited. COPYRIGHT: The Author(s) completely retain the copyright to this published article.

OPEN ACCESS: The Author(s) approves that this article remains permanently online in the open access (OA) model.

QA: This Article is published in line with the principles of "COPE (Committee on Publication Ethics) and PIE (Publication Integrity \& Ethics)". 


\section{INTRODUCTION}

Doxorubicin (DOX) (also known as Adriamycin) is one of the widely used broad spectrum anthracycline antibiotics and one of the most potent cytotoxic drugs use in the clinical management of solid and hematological malignancies (Injac and Strukelj, 2008; Chen et al., 2016). These malignancies include but not limited to cancers of the breast, lungs, thyroid, urinary bladder and ovaries, Kaposi's sarcoma, Hodgkin's lymphoma and acute lymphocytic leukemia for which it is often combined with other cytotoxic agents (Tacar et al., 2013). Its mechanisms of cytotoxic action involve DNA intercalation and inhibition of topoisomerase II, an enzyme which relaxes supercoils in DNA for transcription. Thus, DOX stabilizes the topoisomerase II complex after it has broken the DNA chain for replication, preventing the DNA double helix from being resealed and thereby halting replication (Pommier et al., 2010). It is often combined with other cytotoxic agents such as cyclophosphamide, bleomycin, vinblastine, vincristine, prednisolone, 5-fluoruracil, in cancer treatment "cocktails" (Rivankar, 2014). These "cocktails" include but not limited to combinations involving doxorubicin /cyclophosphamide/ vincristine (for non-oat cell lung carcinoma), doxorubicin/vincristine/prednisolone /etoposide/ cyclophosphamide/bleomycin (for non-Hodgkin's lymphoma), doxorubicin/docetaxel/ cyclophosphamide (for primary breast cancer), doxorubicin/cyclophosphamide (metastatic breast cancer) (Injac and Strukelj, 2008; Jones et al., 2009).

However, despite its wide clinical application in cancer treatment, its use is limited by its off-target common side effects, one of which is hepatorenal toxicity (Guo et al., 2016; Kuzu et al., 2019). There are reports that DOX treatment has been associated with injuries to the heart, and other body organs such as the liver, kidney, brain and testes (Kalender et al., 2005; Bardi et al., 2007; Mohan et al., 2011; Badkoobeh et al., 2013). Studies have also reported that between $30 \%$ and $40 \%$ of cancer patients on doxorubicin treatment suffered hepatotoxicity (Yang et al., 2002; Damodar et al., 2014). Unfortunately, the exact mechanisms involved in DOX-induced hepatic and renal toxicities are complex and remain largely unclear although excessive reactive oxygen species (ROS) generation, oxidative damage and the activation of nuclear factor- $\kappa \mathrm{B}$ have been implicated (Kalender et al., 2005; Lamas et al., 2015). However, in managing DOX-related organ toxicities, pharmacological agents such as antioxidants, hematopoietic cytokines and iron-chelating agents have been studied and proven to have beneficial effects in reducing oxidative stress but associated with little therapeutic benefits in DOX-associated hepatorenal toxicities (Wang et al., 2019). Therefore, the need to identify an effective therapeutic agent against DOXinduced hepatorenal complications becomes challenging (Granados-Principal et al., 2015). In view of this, Clerodendrum volubile ethanol leaf extract is investigated for its possible chemopreventive potential in doxorubicininduced hepatorenal toxicity.

Clerodendrum volubile $\mathrm{P}$. Beauv (belonging to the Labiatae family) is a climbing vegetable of deciduous West African forest and ranging secondary jungles of Senegal to Fernando Po (Burkill, 1985). Its local names include "koywoli" (Susu tribe, Sierra Leone), "nebu" or "sussuru" (Kru tribe, Ivory Coast), "ayadebi" or "nombi" (Kyama tribe, Ivory Coast), "kumamuno" (Akan-Brong tribe, Ghana), "ẹbenote", "nruchi ntà" (Edo and Igbo tribe, respectively, Nigeria) and "ebenetete" among the Itsekiri tribe and "eweta" among the Ilaje people of Nigeria (Erukainure et al., 2014; Happy, 2016). The leaves are generally consumed as vegetable and as soup condiments. Decoctions of Clerodendrum volubile leaves have been used traditionally as pain-killers, sedatives and antiabortifacient (Burkill, 1985) and in the local management of gouty arthritis, rheumatism, dropsy and body swellings/edema (Erukainure et al., 2016). Clerodendrum volubile is reported to contain significant amount of secondary metabolites such as ajugoside, pectolinarigenin, protocatechuic acid, biochanin and 5,7,4'trimethoxykaempferol and other secondary metabolites that have been reported to elicit a very wide range of biological activities including antihyperglycemic, antihyperlipidemic, antihypertensive, anti-inflammatory, antioxidant, hepatoprotective, anticancer, antimicrobial activities (Erukainure et al., 2014; Adefegha and Oboh, 2016; Erukainure et al., 2016, Fred-Jaiyesimi and Adekoya, 2012; Erukainure et al., 2017; Ajao et al., 2018; Erukainure et al., 2018; Afolabi et al., 2019) and in improving cognitive neurodegenerative diseases such as Alzeihmer's disease (Oboh et al., 2017). Recently, we reported the protective effect of $50-400 \mathrm{mg} / \mathrm{kg} / \mathrm{day}$ of Clerodendrum volubile ethanol leaf extract in DOXintoxicated cardiotoxicity in Wistar rats (Olorundare et al., 2020).

In continuation of our investigation into the possible therapeutic potentials of Clerodendrum volubile ethanol leaf extract $(C V E)$ against doxorubicin-induced organ toxicities, this study investigated the possible potential of $C V E$ against DOX-induced hepatorenal toxicities. In addition, the antioxidative profile of $C V E$ in hepatic and renal tissues was evaluated following DOX-induced toxicity. 


\section{MATERIALS AND METHODS}

\section{Plant Materials}

Fresh mature whole plants of Clerodendrum volubile were purchased from herbal vendors in Isikan Market in Akure, Ondo State, Nigeria in the month of March 2019. Samples of the plant were subjected to botanical identification and referencing at the University of Ilorin (UNILORIN) Herbarium, with voucher specimen number: UILH/01/019/1254 allotted.

\section{Extraction Process}

Fresh leaves of Clerodendrum volubile were de-stalked from the whole plant, gently rinsed under running tap water and then air-dried at the room temperature $\left(28-33^{\circ} \mathrm{C}\right)$ until the weight of the leaves was constant. The dried leaves were then pulverized using a milling machine and kept in a water- and air-tight container.

A portion $(1.50 \mathrm{~kg})$ of the pulverized leaves was macerated in 8 liters of absolute ethanol at room temperature for 5 days but intermittently shaken to ensure complete extraction. Thereafter, it was first filtered with cotton wool and then $110 \mathrm{~mm}$ Whatmann filter paper. The resultant filtrate was concentrated in vacuo using a rotary evaporator (B`U'CHI Rotavapor ${ }^{\circledR}$ Model R-215, Switzerland) with Vacuum Module V-801 (EasyVac ${ }^{\circledR}$, Switzerland) set at $70 \mathrm{rpm}$ and $36^{\circ} \mathrm{C}$. Drying was completed over a water bath preset at $40^{\circ} \mathrm{C}$. The darkcolored, sticky and jelly-like, sweet-smelling residue obtained was weighed, stored in air- and water-proof container in a refrigerator. The yield (\% w/w) was calculated using the formula:

\section{Weight of crude extract obtained $(g) \times 100$ Weight of pulverized dried leaf extracted}

\section{Experimental Animals}

Young adult male Wistar rats (aged 8-12 weeks old and weighing 130-190 g) used in this study were obtained from the Animal House of Lagos State University College of Medicine, Ikeja, Lagos State, Nigeria, after an ethical approval for the study (Protocol Identification code: UERC/BMS/134 and UERC Approval number: UERC/ASN/2019/1703) was obtained from the University of Ilorin Ethical Review Committee for Postgraduate Research. The rats were handled in accordance with international principles guiding the Use and Handling of Experimental Animals (US National Research Council Committee for the Update of the Guide for the Care and Use of Laboratory Animals, 2011). The rats were fed ad libitum on standard rat feed (Ladokun Feeds, Ibadan, Oyo State, Nigeria) and potable water. They were maintained at an ambient temperature between $28-30^{\circ} \mathrm{C}$, humidity of 55 $\pm 5 \%$, and 12 hours light and dark cycles.

Table 1: Treatment groups for the study

\begin{tabular}{ll}
\hline Groups & Treatments \\
\hline Group I & $\begin{array}{l}10 \mathrm{~mL} / \mathrm{kg} \text { of distilled water } p . o \text {. for } 14 \text { days }+2.5 \\
\mathrm{mg} / \mathrm{kg} \text { of doxorubicin hydrochloride in normal saline } \\
\text { given } i . p . \text { on alternate days for } 14 \text { days }\end{array}$ \\
Group II & $\begin{array}{l}\text { 200 mg/kg/day of } C V E \text { in } 5 \% \text { DMSO-distilled water } \\
\text { p.o. for } 14 \text { days }+1 \mathrm{~mL} / \mathrm{kg} \text { of normal saline given } i . p .\end{array}$ \\
on alternate days for 14 days
\end{tabular}

\section{Induction of Hepatorenal Toxicity and Treatment}

The rats were randomly allotted into 8 groups of 7 rats per group. Doxorubucin-induced hepatorenal toxicity and subsequent oral treatments with $50-400 \mathrm{mg} / \mathrm{kg} / \mathrm{day} C V E$ for 14 days were done as previously reported by Olorundare et al. (2020). These treatments are as indicated in Table 1. Treated rats were sacrificed and whole blood samples collected with $21 \mathrm{G}$ needle and $5 \mathrm{~mL}$ syringe directly from the heart under inhaled diethyl ether anesthesia. The liver and kidneys were excised and weighed.

\section{Biochemical Assays}

The blood samples were allowed to clot and then centrifuged at $5000 \mathrm{rpm}$ to obtain separate clear sera for serum renal function parameters $\left(\mathrm{Na}^{+}, \mathrm{K}^{+}, \mathrm{HCO}_{3}{ }^{-}, \mathrm{Cl}^{-}\right.$, BUN and creatinine) and were assayed for according to the method described by Imafidon et al. (2019). Hepatic function parameters (AST, ALT, ALP, lipids, total protein, albumin, total bilirubin and conjugated bilirubin) were assayed using methods described by Afsar et al. (2019). 
Measurement of Whole Body and Organ Weights

The rats were weighed on days 1 and 14 of the experiment using a digital rodent weighing scale $\left({ }^{\circledR}\right.$ Virgo Electronic Compact Scale, New Delhi, India). Excised organs were rinsed with normal saline, blotted with filter paper and weighed with electronic balance (Virgo Electronic Compact Weighing Scale, New Delhi, India). The weight of each organ relative to the $100 \mathrm{~g}$ of body weight of the rats from which the organ was excised was calculated as:

\section{Weight of organ $(g) \times 100$ Weight of rat}

\section{Evaluation of Antioxidant Activities in Hepatic and Renal Tissues}

The right lobe of the liver and right kidney was dissected out and immediately rinsed in ice cold $1.15 \% \mathrm{KCl}$ solution in order to preserve the activities of oxidative enzymes. Thereafter, the organs were placed in clean sample bottles in an ice-packed cooler. Superoxide dismutase (SOD), catalase (CAT), reduced glutathione (GSH), glutathione peroxidase (GPx), glutathione-S-transferase (GST) activities and malonialdehyde (MDA) levels were measured using methods described by Weydert and Cullen (2010).

\section{Histology of Liver and Kidney}

Macroscopic examination was performed on the liver and kidney excised from randomly selected rats from each experimental group. After rinsing in normal saline, the organs were preserved in $10 \%$ formo-saline and processed for histological evaluation as previously described by (Slaoui and Fiette, 2011). Each organ sample was embedded in routine paraffin blocks from which 4-5 $\mu \mathrm{m}$ sections were prepared and stained with hematoxylin and eosin. The slides were examined for associated histopathological lesions using procedure earlier described by Slaoui and Fiette (2011).

\section{Chemicals and Reagents}

Doxorubicin hydrochloride (Celondoxily ${ }^{\circledR}$ Injection 50, CELON Laboratories PVT. Limited, Gajularamaram, Ranga Reddy District-500 090, Telangana State, India), test detection kits for the liver and renal function parameters were all procured from Sigma Chemicals Company (St. Louis, MO, USA). All other chemical and reagents used in the experiment were of analytical grade.

\section{Statistical Analysis}

Data are presented as mean \pm S.E.M. of seven observations for the in vivo studies. Statistical analysis was done using one-way analysis of variance followed by posthoc test, Student-Newman-Keuls test on GraphPad Prism
Version 5. Statistical significance was considered at $P<0.05$.

\section{RESULTS}

\section{Percentage Yield}

The extraction of the pulverized dried leaves of Clerodedrum volubile in absolute ethanol was calculated to be $8.39 \% \mathrm{w} / \mathrm{w}$.

\section{Effect of $C V E$ on Body Weight Changes of Doxorubicin-treated Rats}

Table 2 shows the effect of repeated intraperitoneal doxorubicin injections and oral pretreatments with 50, 100,200 and $400 \mathrm{mg} / \mathrm{kg} /$ day of $C V E$ on the average body weight on day 1 and day 14 as well as percentage weight change $(\% \Delta w t$.$) of rats. Doxorubicin treatment caused$ significant and $(P<0.0001)$ reduction in the weight in the rats given doxorubicin only (Group I) when compared to untreated control (normal) rats (Group VIII). Treatment with 50, 100 and $200 \mathrm{mg} / \mathrm{kg}$ of $C V E$, significantly $(P<0.05, P<0.0001)$ caused a dose related increase in the weight of rats (Table 2). Vitamin $\mathrm{C}$ also had similar effect on the weight gain pattern in the doxorubicin-treated rats (Table 2).

Table 2: Effect of repeated oral treatment with 50-400 $\mathrm{mg} / \mathrm{kg} /$ day of $C V E$ on the body weight of doxorubicin-treated rats

\begin{tabular}{|c|c|c|c|}
\hline $\begin{array}{c}\text { Treatment } \\
\text { Groups }\end{array}$ & $\begin{array}{c}\text { Day } 1 \text { Body } \\
\text { Weight } \\
\text { (g) }\end{array}$ & $\begin{array}{l}\text { Day } 14 \\
\text { Body } \\
\text { Weight } \\
\text { (g) }\end{array}$ & $\begin{array}{c}\text { Percentage } \\
\text { Weight } \\
\text { Changes } \\
(\% \Delta w t .)\end{array}$ \\
\hline I & $159.9 \pm 15.1$ & $143.1 \pm 19.0$ & $-10.7 \pm 04.7^{c-}$ \\
\hline II & $178.3 \pm 18.0$ & $191.1 \pm 20.6$ & $07.1 \pm 04.1^{\mathrm{c}+}$ \\
\hline III & $144.2 \pm 15.8$ & $141.5 \pm 25.2$ & $-02.4 \pm 10.5^{\mathrm{a}+}$ \\
\hline IV & $163.9 \pm 08.0$ & $153.0 \pm 11.0$ & $-06.6 \pm 04.8^{a+}$ \\
\hline V & $154.0 \pm 19.6$ & $151.6 \pm 23.1$ & $-09.0 \pm 05.5^{\mathrm{c}+}$ \\
\hline VI & $165.2 \pm 12.4$ & $147.9 \pm 12.8$ & $-10.6 \pm 05.8$ \\
\hline VII & $151.3 \pm 12.9$ & $146.0 \pm 15.4$ & $-03.5 \pm 04.5^{a+}$ \\
\hline VIII & $163.8 \pm 16.8$ & $187.4 \pm 20.2$ & $14.5 \pm 06.2$ \\
\hline
\end{tabular}

c- represents a significant decrease at $P<0.0001$ when compared to untreated (normal) negative control (Group VIII); ${ }^{\text {at }}$ and ${ }^{\mathrm{c}+}$ represent significant increases at $P<0.05$ and $P<0.0001$, respectively, when compared to untreated (doxorubicin-treated) negative control (Group I) values.

\section{Effect of $C V E$ on Relative Liver and Kidneys Weight in Doxorubicin-treated Rats}

Treatment with doxorubicin only and co-treatments with $50-400 \mathrm{mg} / \mathrm{kg} /$ day of $C V E$ induced significant $(P<0.001$, $P<0.0001)$ increases in the relative liver weight when compared to the untreated control (Group VIII) values (Table 3). Similarly, treatment with $20 \mathrm{mg} / \mathrm{kg} / \mathrm{day}$ of 
Vitamin C caused significant $(P<0.0001)$ increase in the relative organ weight in the treated rat weight (Table 3). However, the different doses of $C V E$ did not reverse increase in the relative liver weight induced by doxorubicin treatment (Table 3). There were no significant alterations in the relative kidney weight with CVE pretreatment when compared to Group I values (Table 3).

Table 3: Effect of repeated oral treatment with 50-400 $\mathrm{mg} / \mathrm{kg} /$ day of $C V E$ on the relative hepatic and renal organ weight of doxorubicin-treated rats

\begin{tabular}{lll}
\hline $\begin{array}{c}\text { Treatment } \\
\text { Groups }\end{array}$ & \multicolumn{1}{c}{$\begin{array}{c}\text { Relative } \\
\text { liver weight }\end{array}$} & $\begin{array}{c}\text { Relative } \\
\text { kidney weight }\end{array}$ \\
\hline I & $3.59 \pm 0.24^{\mathrm{c}+}$ & $0.76 \pm 0.10$ \\
II & $2.76 \pm 0.45$ & $0.68 \pm 0.06$ \\
III & $3.41 \pm 0.41^{\mathrm{c}+}$ & $0.76 \pm 0.09$ \\
IV & $3.40 \pm 0.41^{\mathrm{c}+}$ & $0.71 \pm 0.05$ \\
V & $3.21 \pm 0.27^{\mathrm{b}+}$ & $0.74 \pm 0.06$ \\
VI & $3.54 \pm 0.55^{\mathrm{c}+}$ & $0.73 \pm 0.10$ \\
VII & $3.01 \pm 0.24$ & $0.69 \pm 0.09$ \\
VIII & $2.79 \pm 0.18$ & $0.66 \pm 0.05$ \\
\hline
\end{tabular}

${ }^{\mathrm{b}+}$ and ${ }^{\mathrm{c}+}$ represent significant increases at $P<0.001$ and $P<0.0001$, respectively, when compared to untreated negative control (Group VIII) values and untreated positive control (doxorubicin-treated) (Group I) values

Effect of $C V E$ on Serum Lipid Levels of Doxorubicintreated Rats

Administration of doxorubicin resulted in significant $(P<0.0001)$ increase in the serum TG and VLDL-c concentrations while there were no significant alterations in the serum HDL-c, LDL-c concentrations in DOXtreated rats when compared to those of untreated rats (Table 4). However, in rats pretreated with 50-400 $\mathrm{mg} / \mathrm{kg} /$ day of $C V E$ orally, there were significant $(P<0.05$ and $P<0.0001)$ dose unrelated decreases in the serum concentration of TG and VLDL-c without significant alterations in the serum concentration of HDL-c and LDLc when compared to doxorubicin only treated rats (Table 4). Vitamin $\mathrm{C}$ had similar pattern of effects on the measured serum lipids parameters (Table 4).

Effect of $C V E$ on Hepatic Enzymes, Serum Proteins, and Bilirubin in Doxorubicin-treated Rats

Table 5 shows the effect of pretreatment with 50-400 $\mathrm{mg} / \mathrm{kg} /$ day of $C V E$ on serum hepatic enzymes (ALT, AST and ALP), and the levels of total protein (TP), albumin (ALB) and total bilirubin (TB) in doxorubicin-treated rats. Intraperitoneal injection with doxorubicin induced significant $(P<0.01$ and $P<0.0001)$ increases in the serum ALT, AST and ALP levels when compared to untreated normal (Group VIII) values while causing significant $(P<0.05)$ decreases in the serum TP and ALB levels when compared to untreated normal (Group VIII) values (Table
5). However, with oral pretreatment with 50-400 $\mathrm{mg} / \mathrm{kg} /$ day of $C V E$, there were significant $(P<0.05$ and $P<0.0001)$ reversals in the doxorubicin-related alterations of the serum hepatic enzymes, TP and ALB levels bringing these values to values recorded for the untreated control (Group I) rats (Table 5).

Effect of $C V E$ on Renal Function in Doxorubicintreated Rats

Table 6 shows the effect of pretreatment with 50-400 $\mathrm{mg} / \mathrm{kg} /$ day of $C V E$ on the serum electrolytes (sodium, potassium, chloride and bicarbonates), urea and creatinine in doxorubicin-treated rats. Intraperitoneal injection with doxorubicin induced significant $(P<0.001$ and $P<0.0001)$ decreases in the serum $\mathrm{Na}^{+}$and $\mathrm{K}^{+}$levels when compared to untreated normal (Group VIII) values while causing significant $(P<0.05$ and $P<0.001)$ increases in the serum BUN and creatinine $(\mathrm{Cr})$ levels when compared to untreated normal (Group VIII) values (Table 6). However, doxorubicin treatment did not significantly alter serum $\mathrm{HCO}_{3}{ }^{-}$and $\mathrm{Cl}^{-}$levels when compared to the untreated normal (Group VIII) values (Table 6). With oral pretreatments with $50-400 \mathrm{mg} / \mathrm{kg} / \mathrm{day}$ of $C V E$, there were significant $(P<0.05, P<0.001$ and $P<0.0001)$ reversals in the doxorubicin-related alterations of the serum $\mathrm{Na}^{+}, \mathrm{K}^{+}$, BUN and $\mathrm{Cr}$ bringing these values to nearly normal values (Table 6).

Effect of $C V E$ on Hepatic Tissue Oxidative Stress Markers in Doxorubicin-treated Rats

Doxorubicin injection induced significant $(P<0.05$, $P<0.0001)$ decreases in the GST, GPx and CAT activities and GSH levels while significantly $(P<0.05)$ increasing MDA levels in the liver tissues when compared to the untreated control (Group VIII) (Table 7). However, oral pretreatments with $C V E$ significantly $(P<0.05, P<0.001$ and $P<0.0001)$ improved the hepatic GST, GPx and CAT activities while it significantly $(P<0.05$ and $P<0.001)$ reduced MDA levels (Table 7).

\section{Effect of $C V E$ on Renal Tissue Oxidative Stress Markers in Doxorubicin-treated Rats}

Doxorubicin injection induced significant $(P<0.05$, $P<0.001, P<0.0001)$ decreases in the GPx and CAT activities and GSH levels in the liver tissues of doxorubicin-treated rats when compared to the untreated control (Group VIII) (Table 8). However, oral pretreatments with $C V E$ significantly $(P<0.05, P<0.001$ and $P<0.0001)$ improved the hepatic GPx and CAT activities but it significantly $(P<0.0001)$ reduced MDA levels (Table 8). 
Table 4: Effect of 50-400 mg/kg/day of CVE on serum lipid profile of doxorubicin-treated rats

\begin{tabular}{lccccc}
\hline $\begin{array}{c}\text { Treatment } \\
\text { Groups }\end{array}$ & $\begin{array}{c}\text { TG } \\
(\mathbf{m m o l} / \mathbf{L})\end{array}$ & $\begin{array}{c}\text { TC } \\
(\mathbf{m m o l} / \mathbf{L})\end{array}$ & $\begin{array}{c}\text { HDL-c } \\
(\mathbf{m m o l} / \mathbf{L})\end{array}$ & $\begin{array}{c}\text { LDL-c } \\
(\mathbf{m m o l} / \mathbf{L})\end{array}$ & $\begin{array}{c}\text { VLDL-c } \\
(\mathbf{m m o l} / \mathbf{L})\end{array}$ \\
\hline I & $1.3 \pm 0.1^{\mathrm{c}+}$ & $2.3 \pm 0.1^{\mathrm{a}+}$ & $0.6 \pm 0.0$ & $1.2 \pm 0.1$ & $1.3 \pm 0.1^{\mathrm{c}-}$ \\
II & $0.8 \pm 0.2^{\mathrm{d}-}$ & $1.8 \pm 0.2^{\mathrm{d}-}$ & $0.6 \pm 0.0$ & $0.9 \pm 0.1^{\mathrm{d}-}$ & $0.4 \pm 0.1^{\mathrm{f}-}$ \\
III & $0.8 \pm 0.1^{\mathrm{d}-}$ & $2.3 \pm 0.1$ & $0.7 \pm 0.0$ & $1.3 \pm 0.1$ & $0.5 \pm 0.1^{\mathrm{f}-}$ \\
IV & $1.1 \pm 0.1$ & $2.3 \pm 0.1$ & $0.6 \pm 0.0$ & $1.2 \pm 0.1$ & $0.5 \pm 0.1^{\mathrm{f}-}$ \\
V & $0.8 \pm 0.1^{\mathrm{d}-}$ & $2.3 \pm 0.1$ & $0.6 \pm 0.0$ & $1.3 \pm 0.1$ & $0.4 \pm 0.0^{\mathrm{f}-}$ \\
VI & $1.0 \pm 0.1^{\mathrm{d}-}$ & $2.3 \pm 0.2$ & $0.6 \pm 0.0$ & $1.2 \pm 0.1$ & $0.5 \pm 0.1^{\mathrm{f}-}$ \\
VII & $0.9 \pm 0.1^{\mathrm{d}-}$ & $2.1 \pm 0.1$ & $0.6 \pm 0.0$ & $1.1 \pm 0.1$ & $0.4 \pm 0.1^{\mathrm{f}-}$ \\
VIII & $0.6 \pm 0.1$ & $2.0 \pm 0.1$ & $0.6 \pm 0.0$ & $1.1 \pm 0.0$ & $0.3 \pm 0.0^{\mathrm{f}-}$ \\
\hline
\end{tabular}

${ }^{\mathrm{a}+}$ and ${ }^{\mathrm{c}+}$ represent significant increases at $P<0.05$ and $P<0.0001$, respectively, when compared to untreated negative control (Group VIII) value while ${ }^{\mathrm{d}-}$ and ${ }^{\text {f- }}$ represent significant decreases at $P<0.05$ and $P<0.0001$ when compared to untreated positive (doxorubicin treated only) control (Group I) values, respectively. $\mathrm{TG}=$ serum triglyceride; $\mathrm{TC}=$ serum total cholesterol; HDL-c = serum high density lipoprotein-cholesterol; LDL-c = low density lipoprotein-cholesterol; VLDL-c = very low-density lipoprotein-cholesterol. $\mathrm{n}=7$.

Table 5: Effect of 50-400 mg/kg/day of CVE on serum hepatic enzymes, proteins and total bilirubin of doxorubicin-treated rats

\begin{tabular}{lcccccc}
\hline $\begin{array}{c}\text { Treatment } \\
\text { Groups }\end{array}$ & $\begin{array}{c}\text { ALT } \\
(\mathrm{U} / \mathrm{L})\end{array}$ & $\begin{array}{c}\text { AST } \\
(\mathrm{U} / \mathrm{L})\end{array}$ & $\begin{array}{c}\text { ALP } \\
(\mathrm{U} / \mathrm{L})\end{array}$ & $\begin{array}{c}\text { TP } \\
(\mathrm{g} / \mathrm{L})\end{array}$ & $\begin{array}{c}\text { ALB } \\
(\mathrm{g} / \mathrm{L})\end{array}$ & $\begin{array}{c}\text { TB } \\
(\mathrm{mg} / \mathrm{dL})\end{array}$ \\
\hline I & $154.7 \pm 6.3^{\mathrm{c}+}$ & $590.9 \pm 92.0^{\mathrm{c}+}$ & $184.1 \pm 47.4^{\mathrm{a}+}$ & $49.7 \pm 1.7^{\mathrm{a}-}$ & $23.6 \pm 0.7^{\mathrm{a}-}$ & $0.2 \pm 0.0$ \\
II & $104.9 \pm 15.6^{\mathrm{d}-}$ & $595.4 \pm 84.1^{\mathrm{d}-}$ & $141.1 \pm 12.5$ & $66.3 \pm 4.1^{\mathrm{d}+}$ & $28.3 \pm 1.4^{\mathrm{d}+}$ & $0.2 \pm 0.0$ \\
III & $71.9 \pm 2.3^{\mathrm{d}-}$ & $454.7 \pm 60.1$ & $106.4 \pm 13.2^{\mathrm{d}-}$ & $66.6 \pm 2.7^{\mathrm{d}+}$ & $29.3 \pm 0.9^{\mathrm{f}-}$ & $0.2 \pm 0.0$ \\
IV & $47.4 \pm 4.3^{\mathrm{f}-}$ & $241.3 \pm 34.3^{\mathrm{f}-}$ & $111.4 \pm 17.3^{\mathrm{d}-}$ & $54.3 \pm 5.5$ & $23.1 \pm 1.7^{\mathrm{a}-}$ & $0.2 \pm 0.0$ \\
V & $74.4 \pm 6.8^{\mathrm{f}-}$ & $422.1 \pm 43.8^{\mathrm{f}-}$ & $107.9 \pm 22.0^{\mathrm{d}-}$ & $60.0 \pm 1.3^{\mathrm{d}+}$ & $26.3 \pm 0.3^{\mathrm{d}+}$ & $0.1 \pm 0.0$ \\
VI & $51.4 \pm 3.0^{\mathrm{f}-}$ & $351.3 \pm 3.0^{\mathrm{f}-}$ & $88.4 \pm 3.9^{\mathrm{e}-}$ & $54.4 \pm 1.2$ & $25.6 \pm 1.2$ & $0.2 \pm 0.1$ \\
VII & $59.9 \pm 11.9^{\mathrm{f}-}$ & $272.0 \pm 41.2^{\mathrm{e}-}$ & $132.6 \pm 16.9$ & $63.6 \pm 7.8^{\mathrm{d}+}$ & $27.1 \pm 1.1^{\mathrm{d}+}$ & $0.2 \pm 0.1$ \\
VIII & $57.6 \pm 5.8$ & $225.4 \pm 20.7$ & $136.7 \pm 12.3$ & $63.4 \pm 1.7$ & $28.7 \pm 0.9$ & $0.1 \pm 0.0$ \\
\hline
\end{tabular}

${ }^{\mathrm{a}+}$ and ${ }^{\mathrm{c}+}$ represent significant increases at $P<0.05$ and $P<0.0001$, respectively, when compared to untreated negative control (Group VIII) values while ${ }^{\mathrm{d}-, \text { e- }}$ and ${ }^{\text {f- }}$ represent significant decreases at $P<0.05, P<0.001$ and $P<0.0001$, respectively, when compared to untreated positive (doxorubicin treated only) control (Group I) values; ${ }^{\mathrm{d}+}$ represents a significant increase at $P<0.05$ when compared to untreated positive (doxorubicin treated only) control (Group I) values. ALT = serum alanine aminotransferase; AST = serum aspartate aminotransferase; ALP = serum alkaline phosphatase; TP = serum total protein; serum albumin; serum total bilirubin. $\mathrm{n}=7$.

Table 6: Effect of 50-400 mg/kg/day of $C V E$ on serum electrolytes, urea and creatinine (Cr) of doxorubicin-treated rats

\begin{tabular}{lcccccc}
\hline $\begin{array}{l}\text { Group } \\
\mathbf{s}\end{array}$ & $\begin{array}{c}\mathbf{N a}^{+} \\
(\mathbf{m m o l} / \mathbf{L})\end{array}$ & $\begin{array}{c}\mathbf{K}^{+} \\
(\mathbf{m m o l} / \mathbf{L})\end{array}$ & $\begin{array}{c}\mathbf{C l}^{-} \\
(\mathbf{m m o l} / \mathbf{L})\end{array}$ & $\begin{array}{c}\mathbf{H C O}_{\mathbf{3}}{ }^{-} \\
(\mathbf{m m o l} / \mathbf{L})\end{array}$ & $\begin{array}{c}\text { Urea } \\
(\mathbf{m m o l} / \mathbf{L})\end{array}$ & $\begin{array}{c}\text { Creatinine } \\
(\mathbf{m m o l} / \mathbf{L})\end{array}$ \\
\hline I & $154.7 \pm 6.3^{\mathrm{c}+}$ & $590.9 \pm 92.0^{\mathrm{c}+}$ & $184.1 \pm 47.4^{\mathrm{a}+}$ & $49.7 \pm 1.7^{\mathrm{a}-}$ & $23.6 \pm 0.7^{\mathrm{a}-}$ & $0.2 \pm 0.0$ \\
II & $104.9 \pm 15.6^{\mathrm{d}-}$ & $595.4 \pm 84.1^{\mathrm{d}-}$ & $141.1 \pm 12.5$ & $66.3 \pm 4.1^{\mathrm{d}+}$ & $28.3 \pm 1.4^{\mathrm{d}+}$ & $0.2 \pm 0.0$ \\
III & $71.9 \pm 2.3^{\mathrm{d}-}$ & $454.7 \pm 60.1^{\mathrm{f}}$ & $106.4 \pm 13.2^{\mathrm{d}-}$ & $66.6 \pm 2.7^{\mathrm{d}+}$ & $29.3 \pm 0.9^{\mathrm{f}-}$ & $0.2 \pm 0.0$ \\
IV & $47.4 \pm 4.3^{\mathrm{f}-}$ & $241.3 \pm 34.3^{\mathrm{f}-}$ & $111.4 \pm 17.3^{\mathrm{d}-}$ & $54.3 \pm 5.5$ & $23.1 \pm 1.7^{\mathrm{a}-}$ & $0.2 \pm 0.0$ \\
V & $74.4 \pm 6.8^{\mathrm{f}-}$ & $422.1 \pm 43.8^{\mathrm{f}-}$ & $107.9 \pm 22.0^{\mathrm{d}-}$ & $60.0 \pm 1.3^{\mathrm{d}+}$ & $26.3 \pm 0.3^{\mathrm{d}+}$ & $0.1 \pm 0.0$ \\
VI & $51.4 \pm 3.0^{\mathrm{f}-}$ & $351.3 \pm 3.0^{\mathrm{f}-}$ & $88.4 \pm 3.9^{\mathrm{e}-}$ & $54.4 \pm 1.2$ & $25.6 \pm 1.2$ & $0.2 \pm 0.1$ \\
VII & $59.9 \pm 11.9^{\mathrm{f}-}$ & $272.0 \pm 41.2^{\mathrm{e}-}$ & $132.6 \pm 16.9$ & $63.6 \pm 7.8^{\mathrm{d}+}$ & $27.1 \pm 1.1^{\mathrm{d}+}$ & $0.2 \pm 0.1$ \\
VIII & $57.6 \pm 5.8$ & $225.4 \pm 20.7$ & $136.7 \pm 12.3$ & $63.4 \pm 1.7$ & $28.7 \pm 0.9$ & $0.1 \pm 0.0$ \\
\hline
\end{tabular}

${ }^{\mathrm{a}+}$ and $^{\mathrm{c}+}$ represent significant increases at $P<0.5$ and $P<0.0001$, respectively, when compared to untreated negative control (Group VIII) value while ${ }^{\mathrm{d}-, \mathrm{e}^{-}}$and ${ }^{\mathrm{f-}}$ represent significant decreases at $P<0.05, P<0.001$ and $P<0.0001$ when compared to untreated positive (doxorubicin treated only) control values, respectively; ${ }^{\mathrm{d}+}$ represents a significant increase at $P<0.05$ when compared to untreated positive (doxorubicin treated only) control (Group I) values. $\mathrm{n}=7$.

\section{Effect of $C V E$ on the Histology of Liver tissues of Doxorubicin-treated Rats}

Intraperitoneal injection with doxorubicin induced portal vascular congestion and hepatocyte vacuolation (Figure 1) when compared to normal rat hepatocyte (Figure 2). However, there were significant improvements in the DOX-induced hepatic distortion with oral $C V E$ pretreatments especially at $400 \mathrm{mg} / \mathrm{kg} /$ day of $C V E$ which was marked by mildly dilated hepatic sinusoids with bilirubin plugs (Figure 3). Similarly, oral pretreatment 
with vitamin $\mathrm{C}$ also improved DOX-induced hepatic histological distortion which was marked by mild portal vascular congestion and scattered pyknotic nuclei in the hepatocytes (Figure 4).

Table 7: Antioxidant activities of 50-400 mg/kg/day of CVE in doxorubicin-treated rat hepatic tissue

\begin{tabular}{lcccccc}
\hline Groups & $\begin{array}{c}\text { GSH } \\
\text { (U/mg } \\
\text { protein) }\end{array}$ & $\begin{array}{c}\text { GST } \\
\text { (U/mg } \\
\text { protein) }\end{array}$ & $\begin{array}{c}\text { GPx } \\
\text { (U/mg } \\
\text { protein) }\end{array}$ & $\begin{array}{c}\text { SOD } \\
\text { (U/mg } \\
\text { protein) }\end{array}$ & $\begin{array}{c}\text { CAT } \\
\text { (U/mg } \\
\text { protein) }\end{array}$ & $\begin{array}{c}\text { MDA } \\
\text { (U/mg } \\
\text { protein) }\end{array}$ \\
\hline I & $85.7 \pm 5.2^{\mathrm{a}-}$ & $31.1 \pm 0.1^{\mathrm{c}-}$ & $79.5 \pm 4.8^{\mathrm{c}-}$ & $1.7 \pm 0.1$ & $7.7 \pm 1.2^{\mathrm{a}-}$ & $3.4 \pm 0.4^{\mathrm{a}+}$ \\
II & $53.5 \pm 3.3^{\mathrm{f}-}$ & $30.6 \pm 1.4$ & $52.8 \pm 3.2^{\mathrm{e}-}$ & $1.5 \pm 0.1$ & $5.5 \pm 0.3^{\mathrm{b}-}$ & $3.9 \pm 0.3^{\mathrm{a}-}$ \\
III & $78.5 \pm 5.7^{\mathrm{d}+}$ & $31.6 \pm 0.4$ & $77.4 \pm 5.6^{\mathrm{d}+}$ & $1.2 \pm 0.0^{\mathrm{f}-}$ & $6.6 \pm 0.2^{\mathrm{a}-}$ & $3.3 \pm 0.2^{\mathrm{d}-}$ \\
IV & $84.8 \pm 8.2^{\mathrm{e}+}$ & $29.7 \pm 0.7$ & $82.4 \pm 8.3^{\mathrm{d}+}$ & $1.4 \pm 0.1^{\mathrm{e}-}$ & $7.5 \pm 0.5$ & $2.7 \pm 0.5^{\mathrm{e}-}$ \\
V & $50.6 \pm 3.3^{\mathrm{f}-}$ & $35.3 \pm 0.8^{\mathrm{d}+}$ & $53.9 \pm 4.0^{\mathrm{e}-}$ & $1.2 \pm 0.0^{\mathrm{f}-}$ & $7.2 \pm 0.3$ & $3.0 \pm 0.2^{\mathrm{d}-}$ \\
VI & $65.5 \pm 3.4^{\mathrm{d}-}$ & $32.9 \pm 1.0$ & $68.0 \pm 3.0^{\mathrm{d}+}$ & $1.6 \pm 0.0$ & $9.1 \pm 0.3^{\mathrm{d}+}$ & $6.6 \pm 0.8^{\mathrm{f}}$ \\
VII & $122.7 \pm 1.8^{\mathrm{f}+}$ & $43.3 \pm 0.7^{\mathrm{f}+}$ & $134.0 \pm 2.0^{\mathrm{f}+}$ & $1.8 \pm 0.0^{\mathrm{d}+}$ & $10.9 \pm 0.2^{\mathrm{e}+}$ & $3.4 \pm 0.3^{\mathrm{d}-}$ \\
VIII & $105.4 \pm 5.9$ & $41.9 \pm 1.6$ & $115.1 \pm 6.4$ & $1.8 \pm 0.0^{\mathrm{d}+}$ & $9.0 \pm 0.3^{\mathrm{d}+}$ & $3.0 \pm 0.2^{\mathrm{d}-}$ \\
\hline
\end{tabular}

${ }^{\mathrm{a}-}$, and ${ }^{\mathrm{c}-}$ represent significant decreases at $P<0.05$ and $P<0.001$, respectively, when compared to untreated negative control (Group VIII) values. ${ }^{\mathrm{d}+}, \mathrm{e}+$ and ${ }^{\mathrm{f}+}$ represent significant increases at $P<0.05, P<0.001$ and $P<0.0001$, respectively while ${ }^{\mathrm{d}-\text {, }-\mathrm{e}-}$ and ${ }^{\mathrm{f}-}$ represent significant decreases at $P<0.05, P<0.001$ and $P<0.0001$, respectively when compared to untreated positive (doxorubicin treated only) control (Group I) values respectively. GSH = reduced glutathione; GST = glutathione transferase; $\mathrm{GPx}=$ glutathione peroxidase; $\mathrm{SOD}=$ superoxidase dismutase $; \mathrm{CAT}=$ catalase MDA = malondialdehyde dehydrogenase $\mathrm{n}=7$.

Table 8: Antioxidant activities of 50-400 $\mathrm{mg} / \mathrm{kg} /$ day of $C V E$ in doxorubicin-treated rat renal tissue

\begin{tabular}{lcccccc}
\hline $\begin{array}{l}\text { Treatment } \\
\text { Groups }\end{array}$ & $\begin{array}{c}\text { GSH } \\
\text { (U/mg } \\
\text { protein) }\end{array}$ & $\begin{array}{c}\text { GST } \\
\text { (U/mg } \\
\text { protein) }\end{array}$ & $\begin{array}{c}\text { GPx } \\
\text { (U/mg } \\
\text { protein) }\end{array}$ & $\begin{array}{c}\text { SOD } \\
\text { (U/mg } \\
\text { protein) }\end{array}$ & $\begin{array}{c}\text { CAT } \\
\text { (U/mg } \\
\text { protein) }\end{array}$ & $\begin{array}{c}\text { MDA } \\
\text { (U/mg } \\
\text { protein) }\end{array}$ \\
\hline I & $90.1 \pm 4.3^{\mathrm{a}-}$ & $28.7 \pm 0.1$ & $83.6 \pm 4.0^{\mathrm{b}-}$ & $2.0 \pm 0.3$ & $8.1 \pm 0.5^{\mathrm{c}-}$ & $3.3 \pm 0.5$ \\
II & $57.3 \pm 2.0^{\mathrm{f}-}$ & $19.2 \pm 1.4^{\mathrm{f}-}$ & $56.9 \pm 1.9^{\mathrm{f}-}$ & $1.2 \pm 0.1^{\mathrm{d}-}$ & $6.8 \pm 0.3$ & $3.0 \pm 0.3$ \\
III & $106.5 \pm 3.1^{\mathrm{d}+}$ & $20.0 \pm 0.6^{\mathrm{f}-}$ & $105.0 \pm 3.0^{\mathrm{f}+}$ & $1.1 \pm 0.0^{\mathrm{d}-}$ & $7.3 \pm 0.5$ & $3.6 \pm 0.3$ \\
IV & $83.6 \pm 2.9$ & $30.1 \pm 0.4$ & $81.1 \pm 3.9^{\mathrm{f}}$ & $2.2 \pm 0.3$ & $10.2 \pm 0.5$ & $3.6 \pm 0.3$ \\
V & $57.7 \pm 1.7^{\mathrm{f}-}$ & $33.2 \pm 0.8^{\mathrm{et}}$ & $57.0 \pm 1.7^{\mathrm{f}-}$ & $2.0 \pm 0.2$ & $10.8 \pm 1.0$ & $7.6 \pm 0.4^{\mathrm{f}+}$ \\
VI & $58.2 \pm 7.1^{\mathrm{f}-}$ & $35.2 \pm 1.2^{\mathrm{f}+}$ & $56.1 \pm 6.2^{\mathrm{f}-}$ & $3.0 \pm 0.2$ & $13.4 \pm 1.2^{\mathrm{a}+}$ & $6.8 \pm 1.0^{\mathrm{f}+}$ \\
VII & $103.1 \pm 3.9$ & $29.2 \pm 1.3$ & $101.6 \pm 3.9^{\mathrm{e}+}$ & $3.4 \pm 0.1$ & $21.7 \pm 0.7^{\mathrm{f}+}$ & $3.2 \pm 0.2$ \\
VIII & $104.1 \pm 3.8$ & $25.9 \pm 0.3$ & $101.7 \pm 3.7$ & $2.4 \pm 0.2$ & $18.5 \pm 1.6$ & $5.3 \pm 0.3$ \\
\hline
\end{tabular}

${ }^{\mathrm{c}+}$ represent a significant increase $P<0.0001$ when compared to untreated negative (normal) control value while ${ }^{\mathrm{b}-}$ represents significant decreases at $P<0.001$ and $P<0.0001$ when compared to untreated negative (normal) control value control values. ${ }^{\mathrm{d}+,} \mathrm{e}^{\mathrm{e}}+$ and ${ }^{\mathrm{f}+}$ represent significant increases at $P<0.05, P<0.001$ and $P<0.0001$, respectively when compared to untreated positive (doxorubicin treated only) control values respectively while ${ }^{\mathrm{d}-, \mathrm{e}-}$ and ${ }^{\mathrm{f}-}$ represent significant increases at $P<0.05, P<0.001$ and $P<0.0001$, respectively when compared to untreated positive (doxorubicin treated only) control values respectively. GSH = reduced glutathione; GST = glutathione transferase; GPx $=$ glutathione peroxidase SOD = superoxidase dismutase $; \mathrm{CAT}=$ catalase $; \mathrm{MDA}=$ malondialdehyde dehydrogenase. $\mathrm{n}=7$.

\section{Effect of $C V E$ on the Histology of Renal Tissues of Doxorubicin-treated Rats}

Intraperitoneal DOX injection resulted in glomerular atrophy, tubular degeneration with lymphocytic infiltration (Figure 5) compared to normal rat renal architecture (Figure 6). However, oral CVE pretreatment, caused remarkable improvements in the DOX-induced renal histological distortion especially at $400 \mathrm{mg} / \mathrm{kg} / \mathrm{day}$ of $C V E$ which was marked by occasional glomerular atrophy and increased Bowman space with normal adjacent proximal convoluted tubules (Figure 7). Similarly, oral pretreatment with vitamin $\mathrm{C}$ also improved DOX-induced renal histological distortion and this was marked by occasional glomerular cellularity (Figure 8).

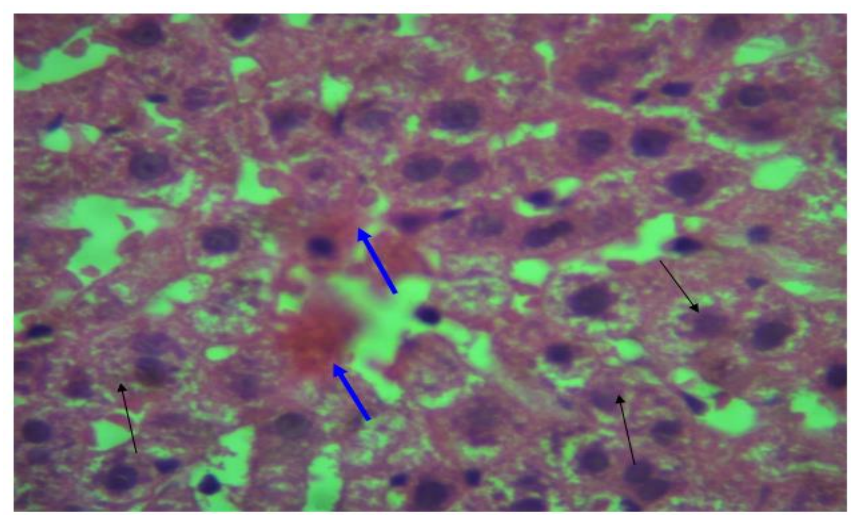

Figure 1: A cross sectional representative of DOX only-treated rat liver showing moderate portal vascular congestion (indicated in blue thick arrow) and hepatocyte cytoplasmic ballooning/vacuolation (in black thin arrows) indicative of hepatic fatty degeneration (x400 magnification, Hematoxylin-Eosin stain). 




Figure 2: A cross sectional representative of the normal rat liver showing normal hepatic histo-architecture (x100 magnification, Hematoxylin-Eosin stain).

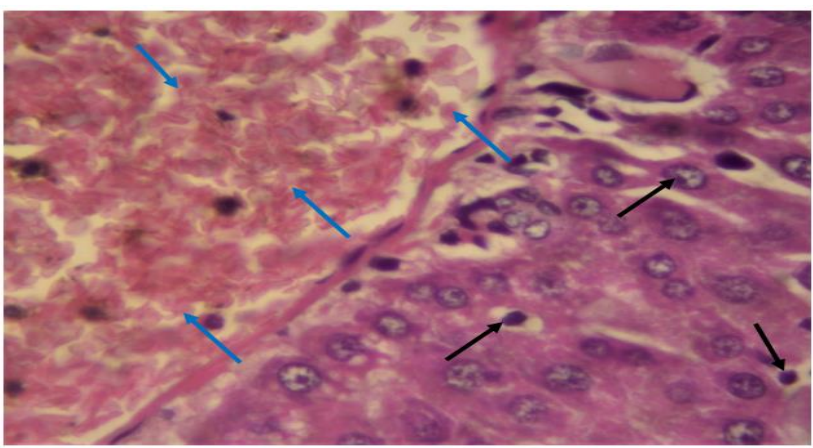

Figure 4: A cross sectional representative of $20 \mathrm{mg} / \mathrm{kg} /$ day of ascorbic acid pretreated, DOX-treated rat liver showing by mild portal vascular congestion (indicated in blue thick arrow) and scattered pyknotic nuclei of hepatocytes (indicated in black thick arrows) suggestive of hepatic recovery from doxorubicin toxicity (x400 magnification, Hematoxylin-Eosin stain).



Figure 6: A photomicrograph of cross sectional representative of a normal rat kidney showing normal glomeruli and tubules (x400 magnification, Hematoxylin-Eosin stain).



Figure 3: A cross sectional representative of $400 \mathrm{mg} / \mathrm{kg} / \mathrm{day}$ of CVE pretreated, DOX-treated liver showing mildly dilated hepatic sinusoids (indicated in blue thick arrows) with bilirubin plugs (indicated in red thin arrows) (x400 magnification, Hematoxylin-Eosin stain).



Figure 5: A cross sectional representative of DOX only-treated rat kidney showing glomerular atrophy (indicated in yellow thick arrows), tubular degeneration with global lymphocytic infiltration (indicated in yellow thin arrows) (x100 magnification, Hematoxylin-Eosin stain).



Figure 7: A photomicrograph of cross-sectional representative of $400 \mathrm{mg} / \mathrm{kg} /$ day $C V E$ pretreated, DOX-treated rat kidney showing occasional glomerular atrophy (indicated in yellow thick arrows) and increased bowman space with normal adjacent proximal convoluted tubules (indicated in green thick arrows) (x100 magnification, Hematoxylin-Eosin stain). 




Figure 8: A photomicrograph of cross-sectional representative of $20 \mathrm{mg} / \mathrm{kg} /$ day of vitamin C pretreated, DOX-treated rat kidney showing occasional glomerular cellularity (indicated in orange thick arrow) and global tubular congestions (indicated in orange thin arrows) (x400 magnification, Hematoxylin-Eosin stain).

\section{DISCUSSION}

Hepatorenal toxicities remain one of the most fatal doselimiting toxicities often associated with DOX treatment (Guo et al., 2016; Kamble and Patil, 2018; Kuzu et al., 2019; Al-Shabanah et al., 2019). In the study, DOXinduced hepatorenal toxicity was established after repeated intraperitoneal DOX injections for 14 days. The hepatic and renal toxicities were measured by the effect of DOX and concomitant $C V E$ treatments on the hepatic and renal function parameters, respectively. The hepatic function endpoints included serum liver enzymes (ALT, AST, ALP and GGT), total proteins, albumin, total bilirubin and lipid profile while the renal function endpoints included serum electrolytes, blood urea nitrogen and creatinine (Ayla et al., 2011). Classically, elevated hepatic transaminase activities are considered reliable index end-points of hepatotoxicity linked to oxidative stress, thus, indicating the source of the hepatic injury (pre-hepatic, intra-hepatic or post-hepatic origin) (Hall and Cash, 2012; ContrerasZentella and Hernández-Muñoz, 2016). Of the hepatic transaminases, ALT which is mainly and abundantly produced and confined to hepatocytes remains the most specific marker of hepatocellular injury (Giannini et al., 2005). Although, AST is present in hepatocytes, its cytosolic isoenzyme is abundantly present in skeletal muscle, heart muscle and kidney tissue also making it less reliable; while ALP which is synthesized in the membranes of cells lining bile ducts and canaliculi is released in response to the accumulation of bile salts or cholestasis (Hall and Cash, 2012). Similarly, gammaglutamyl transferase (GGT) is abundantly present in the liver, kidney, pancreas and intestine. It is found in the microsomes of hepatocytes and biliary epithelial cells.

Thus, serum elevation of GGT in association with a rise in ALP is highly suggestive of a biliary tract obstruction
(Hall and Cash, 2012). Intraperitoneal DOX injections resulted in DOX-induced hepatorenal toxicities which were marked by profound increases in the serum transaminases (ALT and AST), ALP, and profound decreases in the serum TP and ALB without any significant alterations in TB levels which strongly suggest that DOX injury in this study was hepatobiliary in nature. Thus, the results of this study are consistent with those previously reported (Damodar et al., 2014; Chauhan et al., 2016; Anber, 2018). However, the fact that oral pretreatments with $C V E$ profoundly prevented elevations in the serum hepatotoxicity parameters showed that $C V E$ has mitigating effect against DOX-induced hepatotoxicity. These biochemical ameliorations were corroborated by improvement in the histological lesions previously marked by centrilobular necrosis and hepatocyte fatty degeneration. In the same vein, repeated intraperitoneal DOX injection was associated with nephrotoxicity which was marked by significant alterations in serum electrolytes, serum creatinine and serum blood urea nitrogen (Ayla et al., 2011; Rashid et al., 2013; Nagai et al., 2018). Again, these renal function alterations were effectively attenuated by oral pretreatments with $C V E$, and these biochemical attenuations were similar to those also reported by Molehin (2020) with oral pretreatment of methanol leaf extract of Clerodendrum volubile against DOX-induced nephrotoxicity in rats. Improvements in these measured renal function parameters were also corroborated by improvements in the DOX-induced renal histological lesions. However, DOX-induced renal histological lesions could include glomerular vacuolation, sclerosis and atrophy as well as tubular dilatation and necrosis (de Jonge and Verweij, 2006; Lee and Harris, 2011; Kamble and Patil, 2018).

Other notable findings of this study are the effects of DOX and $C V E$ pretreatments on the oxidative stress markers in the hepatic and renal tissues. Doxorubicin, as well as others anthracyclines, are known to also undergo one- and two-electron reduction, being members of the quinone family, and as such generate highly reactive free radicals that can damage macromolecules and lipid membranes through lipid peroxidation mechanism (Injac and Strukelj, 2008). The generation of highly reactive free radicals as metabolites of DOX metabolism is considered to be the primary mechanism of DOX-induced organ toxicities (Quiles et al., 2002; Yilmaz et al., 2005). The mechanisms responsible for DOX-induced hepatorenal toxicities are complex. In recent studies, oxidative stress has been considered as one major mechanism of oxidation-induced hepatorenal toxicities. It is reported that DOX induces oxidative stress that is characterized by ROS accumulation and the decrease of antioxidant defense on oxygen imbalance, culminating in attacking and oxidizing DNA and then inducing liver cell apoptosis (Wang et al., 2019; 
Song et al., 2019). In the present study, DOX-induced hepatorenal toxicities resulted in oxidative stress as evidenced by the reduced GSH levels, reduced GST, GPX and CAT activities; and a high MDA level in the hepatic and renal tissues examined. However, these were effectively ameliorated by $C V E$ and these findings are also similar to those earlier reported by Molehin (2020) in Clerodendrum volubile methanol leaf extract-pretreated DOX-intoxicated renal tissues.

Previous studies have reported CVE to contain abundant secondary metabolites such as saponins, flavonoids and phenols amongst others phytochemicals (Ogunwa et al., 2016; Senjobi et al., 2017; Afolabi et al., 2019). Currently, much attention has been paid to the use of plant secondary metabolites otherwise known as phytochemicals as a protective strategy against DOX-induced organ toxicities including hepatorenal toxicities. Flavonoids are a group of polyphenol compounds that exhibit numerous pharmacological properties that are beneficial for human health partly due to their radical-scavenging, antioxidative, and iron-chelating properties (Kaiserová et al., 2007; Du et al., 2010). Similarly, proanthocyanidins have been reported to ameliorate doxorubicin-induced immunosuppression and hepatorenal toxicity (AbdelSattar et al., 2019). Thus, these phytochemicals are considered potential protectors against DOX-induced hepatorenal toxicities and as such could significantly improve the therapeutic index of DOX (Du et al., 2010; Vaclavikova et al., 2008). The abundant presence of these phytochemicals in $C V E$ could be responsible for the ameliorative effects of $C V E$ in DOX-induced hepatorenal toxicities.

\section{CONCLUSION}

It can safely be concluded that Clerodendrum volubile extract offers protection against DOX-induced hepatorenal toxicities which is mediated via suppression of oxidative stress, free radical scavenging activity and/or antioxidant mechanisms.

\section{ACKNOWLEDGEMENTS}

The authors appreciate the technical assistance provided by the Process Manager, Dr. Obehiaghe A. King, the Laboratory Manager, Dr. Sarah John-Olabode and other staff of the Laboratory Services, AFRIGLOBAL MEDICARE, Mobolaji Bank Anthony Branch Office, Ikeja, Lagos, Nigeria in the assay of the serum hepatic and renal function parameters. Similarly, the technical support of the staff of LASUCOM Animal House, for the care of the experimental animals used for this study and that of
Mr. Sunday O. Adenekan of BIOLIFE CONSULTS in the analysis of oxidative stress markers are much appreciated.

\section{FUNDING}

This research was funded byTertiary Education Trust Fund Nigeria, through its National Research Fund (TETFUND /NRF/UIL/ILORIN/STI/VOL.1/B2.20.12) as a collaborative research award to both Professors Olufunke Esan Olorundare and Hassan Mukhtar.

\section{REFERENCES}

Abdel-Sattar E, Abdelhady DH, Ghazy EW, Abdo W, Elbialy ZI, Shukry M, Mahrous EA, Jandirk S (2019). Proanthocyanidins rich extract of Calligonum comosum ameliorates doxorubicin-induced immunosuppression and hepatorenal toxicity. Pharmacognosy Magazine 15(66): 545-552.

Adefegha SA, Oboh G (20160. Antioxidant and inhibitory properties of Clerodendrum volubile leaf extracts on key enzymes relevant to non-insulin dependent diabetes mellitus and hypertension. Journal of Taibah University of Science 10: 521-533.

Afolabi S, Olorundare O, Gyebi G, Syed DN, Mukhtar H, Albrecht R, Koketsu M (2019). Cytotoxic potentials of Clerodendrum volubile against prostate cell lines and its possible proteomic targets. Journal of Clinical Nutrition and Food Science 2(2): 046-053.

Afsar T, Razak S, Almajwal A (2019). Effect of Acacia hydaspica R. Parker extract on lipid peroxidation, antioxidant status, liver function test and histopathology in doxorubicin treated rats. Lipids in Health \& Disease 18: 126; ～https://doi.org/10.1186/s12944-0191051-2

Ajao AA, Oseni OM, Oladipo OT, Adams YA, Mukaila YO, Ajao AA (2018). Clerodendrum volubile P. Beauv (Lamiaceae), an underutilized indigenous vegetable of utmost nutritive and pharmacological importance. BeniSuef University Journal of Basic and Applied Sciences 7: 606-611.

Al-Shabanah O, Al-Ahmed L, Al-Qunebet R, Al-Yousuf W, Mustafa R, Al-Rejaie S (2019). Losartan and/or naringenin ameliorates doxorubicin induced cardiac, hepatic and renal toxicities in rats. International Journal of Pharmacology 15: 675-685.

Anber ZNH (2018). Effect of doxorubicin and cyclophosphamide regimen versus taxane on liver 
enzymes in Iraqi women with breast cancer. Biomedical Research 29(21): 3869-3873.

Ayla S, Seckin I, Tanriverdi G, Cengiz M, Eser M, Soner BC, Oktem G (2011). Doxorubicin-induced nephrotoxicity: Protective effect of nicotinamide. International Journal of Cell Biology 2011: 390238; https: www.doi.org/10.1155/2011/390238

Badkoobeh P, Parivar K, Kalantar SM, Hosseini SD, Salabat A (2013). Effect of nano-zinc oxide on doxorubicin-induced oxidative stress and sperm disorders in adult male Wistar rats. Iranian Journal of Reproductive Medicine 11: 355-364.

Bárdi E, Bobok I, Voláh A, Kappelmayer J., Kiss C (2007). Anthracycline antibiotics induce acute renal tubular toxicity in children with cancer. Pathology Oncology Research 13: 249-253.

Burkill HM (1985). Useful Plants of West Tropical Africa Kew: Royal Botanic Gardens, Vol. 5.

Chen X, Zhang Y, Zhu Z, Liu H, Guo H, Xiong C, Xie K, Zhang X, Su S (2016). Protective effect of berberine on doxorubicin-induced acute hepatorenal toxicity in rats. Molecular Medicine Reports 13: 3953-3960.

Chauhan P, Yadav R, Kaushal V, Beniwal P (2016). Evaluation of serum biochemical profile of breast cancer patients. International Journal of Medical Research \& Health Sciences 5: 1-7.

Contreras-Zentella ML, Hernández-Muñoz R (2016). Is liver enzyme release really associated with cell necrosis induced by oxidant stress? Oxidative Medicine \& Cellular Longevity 2016: 3529149.

Damodar G, Smitha T, Gopinath S, Vijayakumar S, Rao YA (2014). An evaluation of hepatotoxicity in breast cancer patients receiving injection doxorubicin. Annals of Medical \& Health Sciences Research 4(1): 74-79.

de Jonge MJA, Verweij J (2006). Renal toxicities of chemotherapy. Seminars in Oncology 33: 68-73.

Du G, Lin H, Wang M, Zhang S, Wu X, Lu L, Ji L, Yu L (2010). Quercetin greatly improved therapeutic index of doxorubicin against 4T1 breast cancer by its opposing effects on HIF-1alpha in tumor and normal cells. Cancer Chemotherapy and Pharmacology 65(2): 277-287

Erukainure OL, Ebuehi OAT, Choudhary IM, Adhikari A, Hafizur RM, Perveen S, Muhammad A, Elemo GN (2014). Iridoid glycoside from the leaves of Clerodendrum volubile Beauv. shows potent antioxidant activity against oxidative stress in rat brain and hepatic tissues. Journal of Dietary Supplements 11(1): 19-29.

Erukainure OL, Zaruwa MZ, Choudhary MI, Naqvi SA, Ashraf N, Hafizur RM, Muhammad A, Ebuehi OAT, Elemo GN (2016). Dietary fatty acids from leaves of Clerodendrum volubile induce cell cycle arrest, down regulate matrix metalloproteinase-9 expression, and modulate redox status in human breast cancer. Nutrition and Cancer 68: 634-645.

Erukainure OL, Mesaik MA, Atolani O, Muhammad A, Chukwuma CI, Islam MS (2017). Pectolinarigenin from the leaves of Clerodendrum volubile shows potent immunomodulatory activity by inhibiting T-cell proliferation and modulating respiratory oxidative burst in phagocytes. Biomedicine \& Pharmacotherapy 93: 529535.

Erukainure OL, Hafizur RM, Kabir N, Choudhary MI, Atolani O, Banerjee P, Preissner R, Chukwuma CI, Muhammad A, Amonsou EO, Islam MS (2018). Suppressive effects of Clerodendrum volubile P. Beauv. [Labiatae] methanolic extract and its fractions on type 2 diabetes and its complications. Frontiers in Pharmacology 9: 8 .

Fred-Jaiyesimi A, Adekoya A (2012). Pharmacognostic studies and anti-inflammatory activities of Clerodendrum volubile $\mathrm{P}$ Beauv leaf. International Journal of Phytomedicine 4: 414-418.

Giannini EO, Testa R, Savarino V (2005). Liver enzyme alteration: a guide for clinicians. CMAJ 172(3): 367-379.

Granados-Principal S, Quiles JL, Ramirez-Tortosa CL, Sanchez-Rovira P, Ramirez-Tortosa MC (2010). New advances in molecular mechanisms and the prevention of adriamycin toxicity by antioxidant nutrients. Food \& Chemical Toxicology 48: 1425-1438.

Guo H, Liu Y, Wang L, Zhang G, Su S, Zhang R, Li A, Shang C, Bi B, Li Z (2016). Alleviation of doxorubicin-induced hepatorenal toxicities with sesamin via the suppression of oxidative stress. Human \& Experimental Toxicology 35(11): 1183-1193.

Hall P, Cash J (2012). What is the real function of the liver 'function' tests? The Ulster Medical Journal 81(1): 30-36.

Happy OT (2016). Comparative qualitative analysis of phytochemicals in Baphia pubescens and Clerodendrum volubile leaves. Asian Journal of Ethnopharmacology \& Medicinal Foods 2(1): 18-21. 
Imafidon CE, Akomolafe RO, Eluwole OA, Adekunle IA, Agbaje RA (2019). Aqueous garlic extract improves renal clearance via vasodilatory/antioxidant mechanisms and mitigated proteinuria via stabilization of glomerular filtration barrier. Clinical Phytoscience 5: 27; https://doi.org/10.1186/s40816-019-0118-y

Injac R, Strukelj B. Recent advances in protection against doxorubicin-induced toxicity. Technology in Cancer Research \& Treatment 6(7): 497-516.

Jones S, Holmes FA, O’Shaughnessy J, Blum JL, Vukelja SJ, McIntyre KJ, Pippen JE, Bordelon JH, Kirby RL, Sandbach J, Hyman WJ, Richards DA, Mennel RG, Boehm KA, Meyer WG, Asmar L, Mackey D, Riedel S, Muss H, Savinet MA (2009). Docetaxel with cyclophosphamide is associated with an overall survival benefit compared with doxorubicin and cyclophosphamide: 7-year follow-up of US Oncology Research Trial 9735. Journal of Clinical Oncology 10: 1177-1183.

Kaiserová H, Simůnek T, van der Vijgh WJ, Bast A, Kvasnicková E (2007). Flavonoids as protectors against doxorubicin cardiotoxicity: role of iron chelation, antioxidant activity and inhibition of carbonyl reductase. Biochimica et Biophysica Acta 1772(9): 1065-1074

Kalender Y, Yel M, Kalender S (2005). Doxorubicin hepatotoxicity and hepatic free radical metabolism in rats. The effects of vitamin E and catechin. Toxicology 209: 3945.

Kamble SM, Patil CR (2018). Asiatic acid ameliorates doxorubicin-induced cardiac and hepato-renal toxicities with Nrf2 transcriptional factor activation in rats. Cardiovascular Toxicology 18(2): 131-141.

Kuzu M, Yıldırım S, Kandemir FM, Küçükler S, Çağlayan C, Türk E, Dörtbudak MB. (2019). Protective effect of morin on doxorubicin-induced hepatorenal toxicity in rats. Chemico-Biological Interactions 308: 89-100.

Lamas DJM, Nicoud MB, Sterle HA, Carabajal E, Tesan F, Perazzo JC, Cremaschi GA, Rivera ES, Medina VA (2015). Selective cytoprotective effect of histamine on doxorubicin-induced hepatic and cardiac toxicity in animal models. Cell Death Discovery 1: 15059.

Lee VW, Harris DC (2011). Adriamycin nephropathy: a model of focal segmental glomerulosclerosis. Nephrology 16: $30-38$.

Mohan M, Kamble S, Satyanarayana J, Nageshwar M, Reddy N (2011). Protective effect of Solanum torvum on doxorubicin-induced hepatotoxicity in rats. International Journal of Drug Development \& Research 3: 131-138.

Molehin OR (2020). Alleviation of doxorubicin-induced nephrotoxicity by Clerodendrum volubile leaf extract in Wistar rats: A preliminary study. Journal of Herbmed Pharmacology 9(2): 138-144.

Nagai K, Fukuno S, Otani K, Nagamine Y, Omotani S, Hatsuda Y, Myotoku M, Konishi H (2018). Prevention of doxorubicin-induced renal toxicity by theanine in rats. Pharmacology 101: 219-224.

Oboh G, Ogunruku OO, Oyeleye SI, Olasehinde TA, Ademosun AO, Boligun AA (2017). Phenolic extracts from Clerodendrum volubile leaves inhibit cholinergic and monoaminergic enzymes relevant to the management of some neurodegenerative diseases. Journal of Dietary Supplements 14: 358-371.

Ogunwa TH, Adeyelu TT, Fasimoye RY, Oyewale MB, Ademoye TA, Ilesanmi OC, Awe OB, Ajiboye SA, Oloye BO, Damilola Sholanke D (2016). Phytochemical evaluation and in vitro antioxidant status of Clerodendrum volubile (an indigenous medicinal plant). Pakistani Journal of Pharmaceutical Research 2: 77-88.

Olorundare OE, Adeneye AA,, Akinsola OA, Sanni DA, Koketsu M, Mukthar H (2020). Clerodendrum volubile ethanol leaf extract: A potential antidote to doxorubicininduced cardiotoxicity in rats. Journal of Toxicology 2020: 8859716, 17 pages; https://doi.org/10.1155/2020/8859716

Pommier Y, Leo E, Zhang H, Marchand C (2010). DNA topoisomerases and their poisoning by anticancer and antibacterial drugs. Chemistry \& Biology 17(5): 421-433.

Quiles JL, Huertas JR, Battiono M, Mataix J, RamírezTortosa MC (2002). Antioxidant nutrients and adriamycin toxicity. Toxicology 180: 79-95.

Rashid S, Ali N, Nafees S, Ahmad ST, Arjumand W, Hasan SK, Sultana S (2013). Alleviation of doxorubicininduced nephrotoxicity and hepatotoxicity by chrysin in Wistar rats. Toxicology Mechanisms \& Methods 23(5): 337-345.

Rivankar S (2014). An overview of doxorubicin formulations in cancer therapy. Journal of Cancer Research \& Therapeutics 10(4): 853-858.

Senjobi CT, Fasola TR, Aziba PI (2017). Phytochemical and analgesic evaluation of methanol leaf extract of Clerodendrum volubile Linn. Ife Journal of Science 19: 15. 
Slaoui M, Fiette L (2011). Histopathology Procedures: from tissue sampling to histopathological evaluation. Methods in Molecular Biology 691: 69-82.

Song S, Chu L, Liang H, Chen J, Liang J, Huang Z, Zhang B, Chan X (2019). Protective effects of dioscin against doxorubicin-induced hepatotoxicity via regulation of Sirt1/FOXO1/NF-кb signal. Frontiers in Pharmacology 10:1030

Tacar O, Sriamornsak P, Dass CR (2013). Doxorubicin: an update on anticancer molecular action, toxicity and novel drug delivery systems. The Journal of Pharmacy \& Pharmacology 65(2): 157-170.

US National Research Council Committee for the Update of the Guide for the Care and Use of Laboratory Animals (2011). Guide for the Care and Use of Laboratory Animals. Washington (D.C.): The National Academies Press.

Václavíková R, Kondrova E, Ehrlichova M, Boumendjel A, Kovar J, Stopka P, Souček P, Gut I (2008). The effect of flavonoid derivatives on doxorubicin transport and metabolism. Bioorganic \& Medicinal Chemistry 16: 20342042.
Wang R, Dong Z, Lan X, Liao Z, Chen M (2019). Sweroside alleviated LPS-induced inflammation via SIRT1 mediating NF-kappaB and FoxO1 signaling pathways in RAW264.7 Cells. Molecules 24(5): 872.

Wang Y, Chao X, Ahmad FU, Shi H, Mehboob H, Hassan W (2019). Phoenix dactylifera protects against doxorubicin-induced cardiotoxicity and nephrotoxicity. Cardiology Research and Practice 2019: 7395239; https://doi.org/10.1155/2019/7395239

Weydert CJ, Cullen JJ (2010). Measurement of superoxide dismutase, catalase, and glutathione peroxidase in cultured cells and tissue. Nature Protocols 5(1): 51-66.

Yang XL, Fan CH, Zhu HS (2002). Photo-induced cytotoxicity of malonic acid [C(60)]fullerene derivatives and its mechanism. Toxicology In Vitro 16: 41-46.

Yilmaz S, Atessahin A, Sahna E, Karachan I, Ozer S (2005). Protective effect of lycopene on adriamycininduced cardiotoxicity and nephrotoxicity. Toxicology 218: 164-171. 